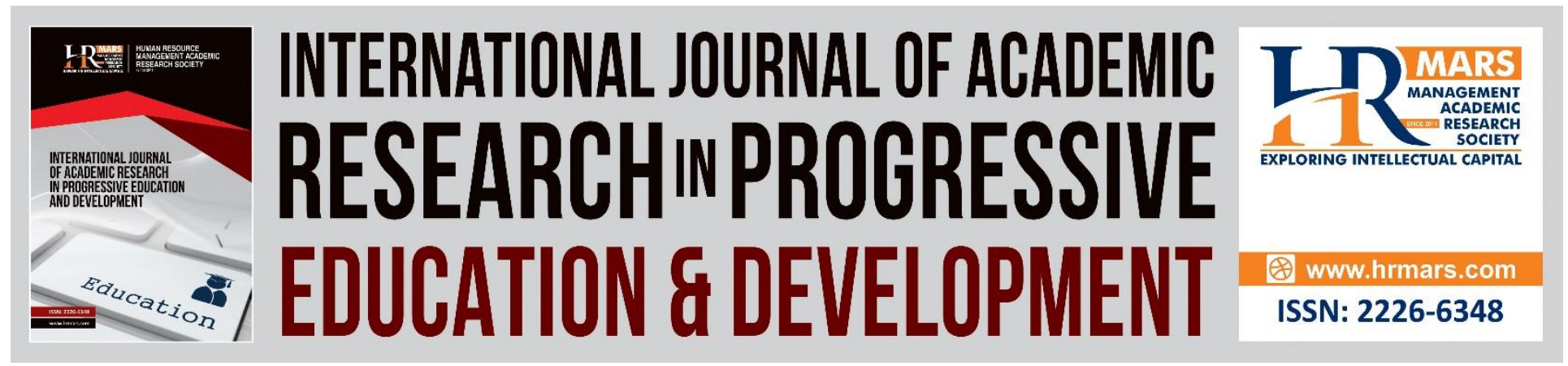

\title{
Issues and Challenges of the Implementation of HOTS in Religious Teaching in Malaysia
}

Nursafra Mohd Zhaffar, Wan Ali Akbar Wan Abdullah, Norasmahani Nor, Nor Anisa Musa, Mohd Syaubari Othman

To Link this Article: http://dx.doi.org/10.6007/IJARPED/v10-i2/9789

DOI:10.6007/IJARPED/v10-i2/9789

Received: 06 February 2021, Revised: 02 March 2021, Accepted: 27 March 2021

Published Online: 21 April 2021

In-Text Citation: (Zhaffar et al., 2021)

To Cite this Article: Zhaffar, N. M., Abdullah, W. A. A. W., Nor, N., Musa, N. A., \& Othman, M. S. (2021). Issues and Challenges of the Implementation of HOTS in Religious Teaching in Malaysia. International Journal of Academic Research in Progressive Education and Development, 10(2), 308-316.

Copyright: (C) 2021 The Author(s)

Published by Human Resource Management Academic Research Society (www.hrmars.com)

This article is published under the Creative Commons Attribution (CC BY 4.0) license. Anyone may reproduce, distribute, translate and create derivative works of this article (for both commercial and non-commercial purposes), subject to full attribution to the original publication and authors. The full terms of this license may be seen at: http://creativecommons.org/licences/by/4.0/legalcode

Vol. 10(2) 2021, Pg. 308 - 316

http://hrmars.com/index.php/pages/detail/IJARPED

JOURNAL HOMEPAGE

Full Terms \& Conditions of access and use can be found at http://hrmars.com/index.php/pages/detail/publication-ethics 


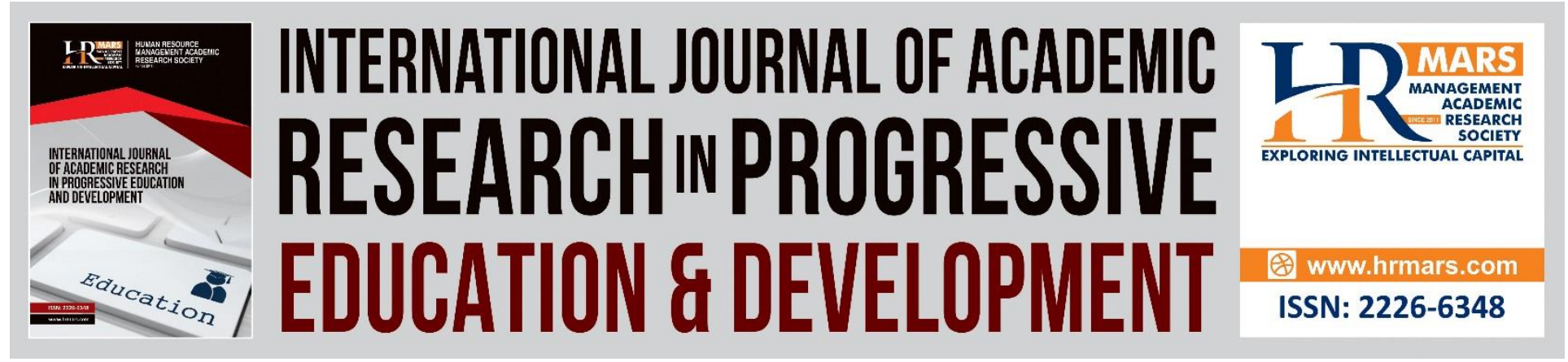

\title{
Issues and Challenges of the Implementation of HOTS in Religious Teaching in Malaysia
}

\author{
Nursafra Mohd Zhaffar ${ }^{1}$, Wan Ali Akbar Wan Abdullah², \\ Norasmahani Nor $^{3}$, Nor Anisa Musa ${ }^{4}$, Mohd Syaubari Othman ${ }^{5}$ \\ ${ }^{1}$ Universiti Teknologi MARA Cawangan Negeri Sembilan, ${ }^{2}$ Fakulti Pendidikan, Universiti \\ Kebangsaan Malaysia, ${ }^{3}$ SMKA Maahad Hamidiah, Kajang, ${ }^{4}$ Bahagian Pendidikan Islam, \\ Kementerian Pendidikan Malaysia, ${ }^{5}$ Universiti Pendidikan Sultan Idris
}

\begin{abstract}
The application of High Order Thinking Skills (HOTS) in the teaching and learning system of Dini Integrated Curriculum (DIC) and Tahfiz Integrated Curriculum (TIC) is in line with its main goal which is to produce balanced and excellent students based on 'aqli and naqli to prepare future scholars and religious muthaqqaf. This is because the ability to relate 'aqli and naqli requires dynamic reasoning ability. However, DIC and TIC are new curricula that have been appointed as the national curriculum in Malaysia. Therefore, this study aims to explore the issues experienced by teachers in conducting HOTS-based teaching in the DIC and TIC curriculum. This study is a qualitative case study conducted on a group of eight experts who are directly involved in the DIC and TIC system. Data were collected using in-depth interviews and analyzed thematically. The findings of the study showed that there are five main issues faced by teachers; namely related to Arabic language proficiency, understanding for the application of HOTs, knowledge of pedagogy, content mastery and student readiness factors. This study is expected to provide recommendations to the Islamic Education Division (BPI) and the Ministry of Education Malaysia (MOE) from the aspect of strengthening the effectiveness of teaching HOTs in religious teaching in Malaysia.
\end{abstract}

Keywords: Higher Order Thinking Skills, Religious Teaching, Teaching and Learning, Issues

\section{Introduction}

The ability to think at a high level is an important element in meeting the challenges of the 21st century today. Furthermore, the borderless world in terms of access to information today requires us to filter and process the information received before it can be used or disseminated. If all of the information in front of us is considered, the negative effects of "information overload," such as anger, discouragement, and jumbled thoughts, will occur due to the dumping of mixed information. This is because the information is seen to be contradictory, meaningless 
and even confusing (Badron, 2009; Daud, 2007). Thus, this situation requires high-order thinking skills (HOTS) to be applied in daily life.

In line with current needs, the education system in Malaysia as well recommends that HOTS be provided to students through its application in the teaching and learning process. It is hoped that through the application of HOTS in the classroom, this helps students explore the meaning of a concept learned creatively and critically for their own use or contribution at the community level (Suhailah, 2007). Similarly, the importance of application in the Dini Integrated Curriculum (DIC) and Tahfiz Integrated Curriculum (TIC) in Malaysia.

DIC and TIC are curricula that have been appointed as the national curriculum began in 2015. Currently, there are 31 schools including Sekolah Menengah Kebangsaan Agama (SMKA) and Sekolah Agama Bantuan Kerajaan (SABK) that run tahfiz programs. Based on the number, 15 of them run the Tahfiz Model Ulul Albab (TMUA) programme, including in four Full Boarding Schools.

The Dini Integrated Curriculum was offered in 180 SABK nationwide. Schools that implement this curriculum need to implement the subjects as a whole according to the packages that have been set. The subjects offered in DIC and TIC are i) Al-Lughah al-Arabiyyah al-Muasiroh (LAM), ii) Usuluddin, iii) Syariah, iv) Manahij al-Ulum al-Islamiyah, v) Al-Adab wa al- Balaghah and Tahfiz subjects for tahfiz schools. All these subjects use Arabic as the medium of instruction in teaching (Islamic Education Division, 2015).

\section{Background Problem}

Higher-order thinking skills (HOTS) are not taught directly in DIC and TIC subjects at the secondary school level. Instead, it is emphasized by infusion or application through the content of subjects involved under this curriculum from Form 1 to Form 5. In this curriculum, there is a need to apply high-level thinking skills based on the main goal of DIC implementation which is to produce balanced and excellent students. based on 'aqli and naqli to prepare future scholars and religious muthaqqaf (Islamic Education Division, 2015). The ability to relate between 'aqli and naqli is a continuous process that can be trained through lesson content with other disciplines as well as the context of daily life. This training requires cognitive competence; the power of a flexible mind in observing and recognizing the surrounding reality as well as adapting to face it.

Therefore, DIC and TIC subjects should not solely concentrate on knowledge transfer and memorization, as this approach does not allow students to improve their critical thinking skills. The knowledge is in fact not only seen in facts and theories only, but its ability to be applied in life. This is because the learning is a gradual process that requires inadequate mastery of knowledge only the understanding of concepts alone, but the ability to be applied, analyzed and evaluated so as to be able to produce a new meaning (Nor et.al, 2015). These skills can help students understand, apply and master learning by evaluating, examining the accuracy, strengths and weaknesses and making judgments based on reasonable reasons and evidence.

Therefore, the teaching style of DIC and TIC must be critical and creative; provide space to develop students' thinking because of its potential in changing students' attitudes and stances towards becoming pious people. Furthermore, religious teachers function not only to produce knowledgeable and skilled students, but to reach out to the formation of noble morals among students (Tamuri, 2015; Tamuri, 2016; Hashim et al., 2014). 


\section{Objective and Research Question of The Study}

In order to strengthen the quality of teaching based on HOTS in DIC and TIC, then the issues and challenges faced by teachers need to be given attention for measures to overcome them. Therefore, this study aims to explore the issues faced by teachers in implementing the application of HOTS in the teaching and learning of DIC and TIC. The research question to be answered is what are the problems or issues faced by teachers to implement HOTS in teaching?

\section{Methodology}

This study used a qualitative design. In-depth interviews were conducted aimed at exploring the understanding from the study participants on the issues faced by teachers in their efforts to implement HOTS in religious teaching. A total of eight experts were selected as study participants using purposive sampling technique. Merriam (2009) suggested that the use of purposeful sampling techniques be initiated by identifying key criteria in the selection of participants. Therefore, the participants of this study were selected based on the criteria, namely i) directly involved in DIC and TIC (either as curriculum drafters, lecturers who provide training to DIC and TIC teachers, or textbook writers who are reference in the DIC and TIC system), ii) served more than 10 years, iii) easy to cooperate. The demographics of the eight study participants are as follows:

Table 1: Demographics of Qualitative Participants

\begin{tabular}{lllll}
\hline No. & Items & Demographics & Quantity & Amount \\
\hline 1 & Role & $\begin{array}{l}\text { DIC/TIC drafter } \\
\text { DIC/TIC teacher } \\
\text { trainer } \\
\text { Textbook author }\end{array}$ & 3 & \\
& & 2 & 8 \\
\hline 2 & Educational & PhD & 5 & \\
& Background & & 3 & \\
\hline 3 & Occupation & IPT/IPG lecturer & 4 & \\
& & MOE officers & 2 & 8 \\
& & Teacher & 2 & \\
\hline
\end{tabular}

This study has obtained written permission from the Education Policy Planning and Research Division (EPRD), Ministry of Education Malaysia. Meanwhile, all study participants gave their consent and willingness to be study participants. Because the study took place during the Covid-19 pandemic season that hit the country and the direction of the Movement Control Order from the government, the data collection of these interviews was conducted entirely online through the Google Meet app. These interviews were recorded and then these recordings were transcribbed for analysis.

Interview data were analyzed thematically. Key themes are highlighted to answer the research questions. The constant comparison method is also used. These comparisons were made against the study data between study participants at different interview sessions to identify patterns of similarities and differences in the data (Strauss \& Corbin, 1998). To ensure the validity 
Vol. 10, No. 2, 2021, E-ISSN: $2226-6348$ @ 2021 HRMARS

and reliability of the data, the researcher conducted a process of member checks with the study participants. This strategy is done through the validation of study participants on the interpretation and summary of the meaning of the data obtained from them. This is to prevent researchers from reporting findings that are contrary to the original intent of the study participants.

\section{Findings}

To answer the research objective that is what are the problems or issues faced by teachers to implement HOTS in teaching DIC and TIC, there are five themes which include i) proficiency in Arabic language, ii) HOTS application, iii) pedagogical knowledge, iv) mastery of lesson content and $v$ ) student readiness.

\section{i) Proficiency in Arabic}

The main problem is related to the weakness of Arabic proficiency among teachers and students. The majority of study participants are of the view that the situation of teachers who are less proficient in using Arabic is a major problem for applying HOTS in teaching. There are a few teachers confess to speaking Arabic in the classroom with limited proficiency. This situation arises for two reasons, namely; i) less use of Arabic in daily speech, and ii) less confidence in using it in teaching and learning sessions. The issue of lack of confidence on the part of teachers is due to the educational background of teachers and the category of teachers who have just started the service. This is the same as stated by the expert, Ustaz M, "There are also language issues. Some of these teachers complained that they had never taught in Arabic before. And their degree or education is just Islamic studies in general. "As a result, the HOTS application cannot be conducted properly due to this problem.

Restrictions on the use of Arabic were noted by Dr. J, "Teachers have problems with their command of Arabic, while the instruction needs to take place in Arabic. How to stimulate students' thinking to a higher level? Simply put there must be reciprocity. Students also need to master the language. "Study participants explained that these students with poor proficiency in Arabic affected their basic knowledge in the subjects studied. Without this basic knowledge, the HOTS stimuli that teachers run get less response from students. This situation disrupts students' interest in the subject, not to mention if prompted to think more deeply about the content of the lesson. Teachers acknowledge that students not only have difficulty communicating with teachers in Arabic, but even expect the teacher to translate each word in the textbook as a step towards understanding the content of the lesson.

\section{ii) HOTS Application}

The second problem is related to lack of skills to apply HOTS. Most of the study participants are of the view that the DIC and TIC systems are still new. This situation has resulted in a lack of guidance on HOTS specifically based on the disciplines of DIC and TIC being disclosed. They expect there to be guidelines such as sharing experiences on the application of HOTS whether in the form of pedagogical references to HOTS, instruments, question items, teaching aid materials and so on. There are also teachers who associate this HOTS application with questioning methods. 
According to the study participants, teachers are less exposed to questioning methods to stimulate students' high -level thinking in the DIC and TIC system.

However, for Dr. P, in reality, some teachers use HOTS without even realizing it. Clearly Dr. P, "All this time we (teachers) have been teaching. When teaching, we do the process of analysis, of course brought forth students who memorize the Qur'an, there needs to be analysis, assessment, there needs to be invention. But the process takes place without us realizing it. We never discussed (in class) that what I did earlier was the HOTS process. "

\section{iii) Pedagogical Knowledge}

In addition, study participants stated that teachers lacked knowledge about pedagogy. For them, effective pedagogical methods are needed to encourage students to think critically and creatively. This situation occurs because teachers are tied to the teaching style of their previous teachers during their time of study. This is explained by Dr. H, "Religious teachers are limited to the sekolah pondok method, especially those familiar with translation methods.... When tied to the teacher-centered method, then the opportunity for students to show creativity of thought is less."

Study participants explained that teachers admitted that they still did not fully understand the need or importance of the application of HOTS in teaching. These findings are in line with the views of Dr. P is the perception of teachers who see no importance of the element of HOTS in the hifz al-Quran can be a constraint to the application, "For them (teachers), he has never heard the term of HOTS. How is it ustaz for us to memorize the Quran in its nature for memorization? There is the highest level (thinking) for the production of students who memorize the Quran. " An understanding of HOTS, needs and methods of applying the elements of HOTS in teaching can be revealed to teachers through effective pedagogical training.

\section{iv) Mastery of Lesson Content}

The next problem is related to teachers who lack mastery of the content of the lesson. Study participants felt that lack of knowledge in a topic or issue hindered in-depth and critical discussion. This was acknowledged by an expert, Ustaz M, "Before the HOTS, the material in the book must be understood first! Especially the title of Shariah. In a Shariah topic, if you just know Arabic but don't understand the problem, it won't end."

Issue on the content mastery has several causes, among them as revealed by the teachers; i) non-field teachers who teach certain subjects in DIC and TIC, ii) time constraints cause teachers not to have the opportunity to deepen the knowledge they want to teach in critical way, iii) DIC and TIC lesson content is too high, and iv) the use of high register language in a textbook. This situation makes the content difficult to explain to students widely.

\section{v) Student Readiness}

The next constraint faced by teachers to implement HOTS in teaching is related to students. Pupils who are not prepared with initial information on the topics discussed become a barrier to teachers to implement HOTS in teaching. When students are not ready, then classroom activities receive less active response because students do not have basic knowledge. This situation is also related to the weakness of Arabic language proficiency among students. In addition, students' 
focus to the contents of the textbook only so that it is difficult to be asked to think outside the box.

In conclusion, five problems have been identified as issues and challenges to the practice of HOTS in religious teaching focus on DIC and TIC curriculum. From these five problems; four of which come from the teacher, while two problems stem from the students. The issue of Arabic language proficiency is a problem faced by both parties. These issues briefly can be understood through the model below:

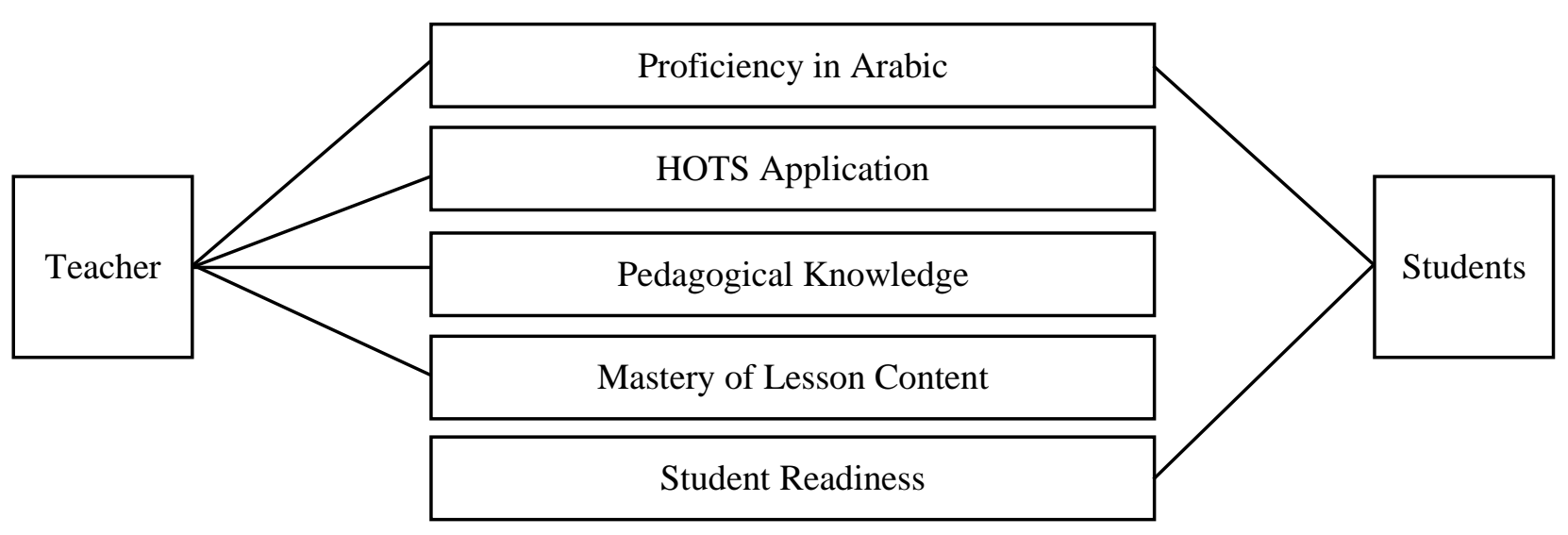

Figure 1: HOTS Implementation Issues in Religious Teaching Model

\section{Discussion}

The issue of Arabic language proficiency is a major constraint to apply the elements of HOTS in the teaching and learning of DIC and TIC. These findings are in line with the study of Ghani et. al (2018) who found that the Arabic communication environment in SABK is at a less encouraging level. Thus, weakness from the aspect of language can be a barrier factor because language is a medium to move one's understanding and rationality towards something (Haddad, 1974; Fisher, 2007) where this element is necessary to generate high-level thinking. Barriers to Arabic language skills either on the part of teachers or students can affect the understanding of the basic concepts of lesson content.

Without mastery of basic concepts, it is difficult for teachers to stimulate students' HOTS in the classroom. This is because the students' understanding of the basic concepts becomes a thinking material that will be blended, combined and analyzed to obtain a new understanding as a result of the thinking. The same goes for teachers. Teachers need to master the content of the lesson well and even include other sciences related to it. This extensive and in-depth mastery of knowledge can encourage teachers to create an information-rich classroom atmosphere. Thus, in such stimulus situations, students can see and engage with their teachers to organize and apply basic knowledge or information into different contexts. An active thinking process in the teaching and learning (T\&L) process can contribute to the effectiveness of lessons.

The researcher believes that preparation for HOTS-based teaching is a full-time job for a teacher. This is because it relates to the mastery of knowledge possessed by the teacher. Like students, teachers also build competencies gradually through knowledge and experience 
(Darling-Hammond, 2008). Thus, the weakness of language proficiency, understanding and skills to apply the concept of HOTS and the issue of mastery of lesson content can be overcome gradually through the commitment and commitment of teachers to increase knowledge.

In addition, this is also closely related to the issue of adequacy and effectiveness of the courses and training they receive. Teachers in the DIC and TIC system need to receive adequate training and courses specifically to implement pedagogy to stimulate students' HOTS thinking. Teachers need to master strategies related to pedagogy and teaching delivery such as teaching structuring, questioning, providing feedback and modeling to be applied directly in teaching. Therefore, the Institute of Teaching and the Division of Teacher Services and Training should increase training and practical courses for teachers in specialized services for the teaching of thinking. The effectiveness of the course should also be emphasized.

The success of the application of HOTS in T\&L sessions does not solely depend on the role of teachers alone. However, students also need to be prepared for active learning and respond positively in learning. These findings are in line with the previous studies of al-Zarnuji (2004), Sternberg (1987) and Hamzah et. al (2018) who stressed that not only teachers need to work hard to develop students' thinking, but on the part of students also need to work in the same direction. In the context of this study, teachers can invite students to think by cultivating patterns of classroom handling towards the encouragement of critical and creative thinking. Although teaching targets to low-achieving students, but the teacher's wisdom in manipulating students' prior experiences can help students relate lessons to their daily lives. So, starting with the habit of this linking process makes students comfortable if driven to high-level thinking activities in accordance with the need to face future challenges.

\section{Conclusion}

In conclusion, this study displays the issues faced by teachers to implement HOTS in religious curricula; DIC and TIC. This study has implications for the Ministry of Education to conduct continuous training to increase professionalism among DIC and TIC teachers. Among the trainings that can be organized to improve the understanding and application of HOTS teaching among DIC and TIC are such as content knowledge improvement courses, HOTS pedagogy workshops by subject matter, Arabic communication workshops and so on. Meanwhile, the school or the District Education Office should provide access to rich resources. It is suggested to establish a one-stop center as a platform to share materials related to HOTS among religious DIC and TIC teachers. This platform can be accessed by all DIC and TIC teachers, either as material contributors, or want to find related materials. There is also a need for school management to design activities that can encourage the use of Arabic among school people.

\section{References}

Tamuri, A. H. (2007). Islamic Education teachers' perceptions of the teaching of akhlāq in Malaysian secondary schools. Journal of Moral Education, 36(3), 371-386.

Tamuri, A. H. (2015). Standardization of Islamic Education excellence in the world. Tinta Artikulasi Membina Ummah, 1(2), 109-120. 
Tamuri, A. H. (2016). Keberkesanan guru dalam pengajaran dan pembelajaran mata pelajaran Pendidikan Islam. In Mohd Farid Mohd Shahran \& Nor Hartini Saari (Eds.), Guru Cemerlang Pendidikan Islam: Persediaan dan Cabaran (pp. 1-30). IKIM Press.

Darling-Hammond, L. (2008). Teacher Learning that Supports Student Learning. Presseisen, B. Z. Teaching for Intelligence Second Edition. Corwin Press.

Fisher, R. (2007). Dialogic teaching: developing thinking and metacognition through philosophical discussion. Early Child Development and Care 177 (6-7): 615-631.

Haddad, F. S. (1974). An early Arab theory of instruction. International Journal of Middle East Studies 5(3): 240-259.

Hamzah, M. I., Zhaffar, N. M. \& Razak, K. A. (2018). Barriers in teaching critical thinking in Islamic education. Creative Education, 9(14), 2350-2356. https://doi.org/10.4236/ce.2018.914175

Islamic Education Division. (2015). Maklumat Asas Pelaksanaan Kurikulum Bersepadu Dini. Kementerian Pendidikan Malaysia.

Ghani, K. A., Hassan, A. T,, Rahman, A. A., Noh, M. A. C., Mat, M. Z. A., Ismail, Z., Hashim, A., Hussin, S., Habil, R. \& Salleh, S.A.M. (2018). Pelaksanaan bahasa Arab dalam pelaksanaan Kurikulum Bersepadu Dini di SABK. Jurnal Sultan Alauddin Sulaiman Shah Special Issue (2018): 644-656.

Merriam, S. B. (2009). Qualitative Research: A Guide to Design and Implementation. San Francisco: John Wiley \& Sons.

Badron, M. S. (2009). Zaman ledakan maklumat dan kemajuan pengetahuan dalam kerangka pandangan hidup Islam. AFKAR 10: 83-108.

Nor, N., Suhaimi, N., Wahab, N. S. A., Ismail, M. K. C., Noh, M. A. C., \& Razak, K. A. (2015). Pelaksanaan KBAT dalam Pengajaran dan Pembelajaran Pendidikan Islam Sekolah Menengah: Satu Tinjauan di Putrajaya. Proceeding of 7th International Seminar on Regional Education (1), Pekan baru Riau Indonesia, (pp. 361-375).

Hashim, R., Hussien, S., \& Juperi, J. A. (2014). The Hikmah (Wisdom) Program: A philosophical inquiry for the teaching of Islamic education in Malaysia. In S. Buang \& P. G. Chew (Eds.), Muslim education in the 21 $1^{\text {st }}$ Century (pp.124-141). Routledge. https://doi.org/10.4324/9781315817873

Sternberg, R. J. (1987). Teaching critical thinking: eight easy ways to fail before you begin. The phi delta kappan 68(6), 456-459.

Strauss, A., \& Corbin, J. (1998). Basics of Qualitative Research: Techniques and Procedures for Developing Grounded Theory. Sage Publication Inc.

Hussien, S. (2007). Critical pedagogy, islamisation of knowledge and muslim education. Intellectual discourse, 15(1), 85-104.

Https://journals.iium.edu.my/intdiscourse/index.php/id/article/view/62

Daud, W. M. N. W. (2007). Budaya IImu: Satu Penjelasan. Singapore: Pustaka Nasional Pte Ltd.

Al-Zarnuji, B. I. (2004). Ta'lim al-Muta'alim Thariq al-ta'llum. Al-Dar Al Soudania for Books. 